\title{
Effects of medicinal plants mixture on growth performance, nutrient digestibility, blood profiles, and fecal microbiota in growing pigs
}

\author{
Nguyen Cong Oanh ${ }^{1,2}$, Truong Quang Lam ${ }^{3}$, Nguyen Dinh Tien ${ }^{1}$, Jean-Luc Hornick ${ }^{1,2}$ (D) and Vu Dinh Ton ${ }^{1}$ (D)
}

1. Vietnam National University of Agriculture, Faculty of Animal Science, Ngo Xuan Quang Street, Trauquy, Gia Lam, 100000 Hanoi, Vietnam; 2. University of Liège, Faculty of Veterinary Medicine, FARAH Center, Department of Veterinary Management of Animal Resources, Quartier vallée 2, Avenue de Cureghem 6, B43a, 4000 Liège, Belgium; 3. Vietnam National University of Agriculture, Faculty of Veterinary Medicine, Key Laboratory for Veterinary Biotechnology, Ngo Xuan Quang Street, Trauquy, Gia Lam, 100000 Hanoi, Vietnam.

Corresponding author: Nguyen Cong Oanh, e-mail: ncoanh@gmail.com

Co-authors: TQL: truongquanglam2806@gmail.com, NDT: ndtien.hd@gmail.com,

HJ: jlhornick@uliege.be,VDT: vdton@vnua.edu.vn

Received: 03-03-2021, Accepted: 15-06-2021, Published online: 24-07-2021

doi: www.doi.org/10.14202/vetworld.2021.1894-1900 How to cite this article: Oanh NC, Lam TQ, Tien ND, Hornick J-L, Ton VD (2021) Effects of medicinal plants mixture on growth performance, nutrient digestibility, blood profiles, and fecal microbiota in growing pigs, Veterinary World, 14(7): 1894-1900.

\begin{abstract}
Background and Aim: Alternative natural materials to antibiotics for improving digestive health and growth performance are needed due to strengthening regulations related to the use of antibiotic growth promoters. The study aimed to evaluate the effects of medicinal plants mixture (60\% Bidens pilosa L., 15\% Urena lobata L., 15\% Pseuderanthemum palatiferum, $5 \%$ Ramulus cinnamomi, and 5\% Star anise) as alternative growth promotors on animal health, nutrient digestibility, blood parameters, and growth performance of growing pigs.

Materials and Methods: The study was conducted, from April 2020 to June 2020, at a private pig production farm located in Cam Giang district Hai Duong Province, Vietnam. Forty-eight 10 -week-old crossbred ( ${ }^{\star}$ Duroc $\times \uparrow$ [Landrace $\times$ Yorkshire]) pigs, average initial body weight $30.3 \pm 1.42 \mathrm{~kg}$, were randomly allocated to four dietary groups, three replicate pens per experimental group, with 4 pigs/pen. For 7 weeks, the pigs were fed a basal diet supplemented with the mixture at levels of $0,20,40$, and $60 \mathrm{~g} / \mathrm{kg}$ of feed.

Results: Final body weight, average daily gain, average daily feed intake, and feed conversion ratio, as well as apparent total tract digestibility of dry matter, organic matter, crude protein, ether extract, and gross energy were not significantly influenced by the diets ( $>0.05)$. Inclusion of the plant mixture decreased significantly red blood cell count, blood cholesterol, urea nitrogen, and low-density lipoprotein $(\mathrm{LDL})$ concentrations $(\mathrm{p}<0.05)$ compared with the control diet. No diet effect was observed on fecal Escherichia coli, Salmonella spp., Clostridium spp., and total bacteria counts.
\end{abstract}

Conclusion: The incorporation of the plant mixture into the diet of growing pigs reduced serum cholesterol, LDL, and urea concentrations with no adverse effect on performance and nutrient digestibility.

Keywords: animal performance, blood profile, digestibility, growing pig, medicinal plants powder.

\section{Introduction}

Overuse of antibiotics for growth promotion and disease prevention in animals can contribute to the emergence of antibiotic resistance and increase human health risks [1]. Therefore, many countries have already taken action to reduce the use of antibiotics in food-producing animals. European Union has banned the use of antibiotics for growth promotion since 2006. Since then phytogenic compounds have been studied and used in animal feeds with the objectives to substitute antibiotics as growth promoters and disease prevention or treatment [2-5].

Several herbal extracts have been reported to promote feed intake, feed digestibility, and beneficial

Copyright: Oanh, et al. Open Access. This article is distributed under the terms of the Creative Commons Attribution 4.0 International License (http://creativecommons.org/licenses/by/4.0/), which permits unrestricted use, distribution, and reproduction in any medium, provided you give appropriate credit to the original author(s) and the source, provide a link to the Creative Commons license, and indicate if changes were made. The Creative Commons Public Domain Dedication waiver (http://creativecommons.org/ publicdomain/zero/1.0/) applies to the data made available in this article, unless otherwise stated. intestinal microbiome and also to improve immune system [6,7]. Medicinal plants Ramulus cinnamomi (Cinnamon twig), Star anise (Illicium verum Hook. f.), Bidens pilosa L., Urena lobata L., and Pseuderanthemum palatiferum are widely distributed in tropical and sub-tropical areas of Asia, especially Vietnam, and are considered as feed additives for animals [8]. The phytochemical components of these plants are tannins, saponins, phenols, alkaloids, and glycoside [9-13], which are known to be potential sources of useful drugs [14], especially exhibiting high antibacterial, immune, and antioxidant properties [12,15-18]. Flavonoids of $B$. pilosa protect the liver function by limiting an increase in hepatic levels of alanine aminotransferase (ALT) and aspartate aminotransferase (AST) on the carbon tetrachloride model in mice and no evidence of animal toxicity at $160 \mathrm{~g} / \mathrm{kg}$ of animal live weight was observed [19]. A previous in vitro study [20] reported that water extract of B. pilosa had higher activity against Bacillus cereus and Escherichia coli than gentamycin sulfate. Dried and fresh leaves of $P$. palatiferum are used to treat diarrhea in piglets [21]. Recent in vitro studies [22,23] showed 
that Star anise and $R$. cinnamomi inhibited replication of influenza and flu virus. Moreover, weaning pigs fed a diet supplemented with $0.05 \%$ S. anise oil had a higher average daily gain (ADG) than those fed a control diet [24]. As far as we know, no studies reported the effects of a blend of more than 2 herbal plants of B. pilosa, P. palatiferum, U. lobata, R. cinnamomi, and $S$. anise on pig production.

The study aimed to evaluate the effects of medicinal plants mixture $(60 \% \mathrm{~B}$. pilosa L., $15 \%$ U. lobata L., $15 \%$ P. palatiferum, 5\% R. cinnamomi, and 5\% $S$. anise) as alternative growth promotors on animal health, nutrient digestibility, blood parameters, and growth performance of growing pigs.

\section{Materials and Methods}

\section{Ethical approval}

In the absence of proper regulation in Vietnam, all procedures included in the experiment were performed according to the best practices recommended by the ethical committee for experiments in animals of University of Liège, Belgium.

\section{Study period and location}

The study was conducted from April 2020 to June 2020 at a private pig production farm located in Cam Giang district, Hai Duong Province, between latitude $20^{\circ} 57^{\prime} 0$ " E and longitude $106^{\circ} 13^{\prime} 0^{\prime \prime}$ E.

\section{Preparation of the medicinal plants}

The plant species were chosen according to their availability around the farm and their constituents. Aerial parts of $P$. palatiferum, U. lobata, and B. pilosa were harvested during the vegetative growth phase at the medicinal garden of private agricultural farms located Cam Giang district, Hai Duong Province, Vietnam. $R$. cinnamomi and $S$. anise only were harvested during fructification from a forest garden at Huu Lung district, Lang Son Province, Vietnam.

The plants were dried separately in an oven at $60-75^{\circ} \mathrm{C}$ for $8 \mathrm{~h}$. After drying, their materials were separately stored in air-tight bags. They were ground into fine powder and proportionally mixed as a powder (MP) containing 60\% B. pilosa, 15\% U. lobata, $15 \% P$. palatiferum, $5 \% R$. cinnamomi, and 5\% $S$. anise. The weight contribution $(60: 15: 15: 5: 5)$ of the medicinal plants in the mixture was determined by the availability of resources, their costs, and the recommendations of traditional medicine.

\section{Experimental design}

Forty-eight crossbred ( $\overbrace{}^{1}$ Duroc $\times$ ? [Landrace $\times$ Yorkshire]) pigs, originating from eight sows, 3 to 4 litters order, initial body weight (IBW) $30.3 \pm 1.42$ (SD), and age about 10 weeks old were used in this experiment. The pigs were individually ear tag numbered and randomly allocated to the four dietary treatments according to similar IBW, sex, and sow origin by treatment. There were three replicate pens per treatment, two barrows, and two gilts per pen $(2 \mathrm{~m} \times 3 \mathrm{~m})$ equipped with one stainless steel feeding and two automatic water drinking nipples. Animals were kept in a climate-controlled building with the temperature between 27 and $29^{\circ} \mathrm{C}$, and the relative humidity between 70 and $85 \%$.

Raw feed ingredients were purchased all at once from a local feed company. Feed was ground into flour through a $2 \mathrm{~mm}$ screen before the basal diet (T0) formulation. The experimental diets (T1, T2, and T3) were made of the basal diet mixed with MP at 20, 40, and $60 \mathrm{~g} / \mathrm{kg}$, respectively). Each was offered during a total experiment duration of 49 days. In the 2 last week of the experiment, chromium oxide $\left(\mathrm{Cr}_{2} \mathrm{O}_{3}\right)$ was added at a level of $5 \mathrm{~g} / \mathrm{kg}$ of diet, as an inert marker to measure digestibility parameters.

The complete diets were collected for chemical analysis. The basic ingredients and nutrient levels of the diets are shown in Table-1 [25]. The nutrients composition of the diets met the recommended requirements for growing pigs [26]. Pigs were fed ad libitum during the whole experimental period and animals had free access to water by nipple drinkers.

\section{Measurements}

\section{Animal performance}

The animals were individually weighed at the start and the end of the experiment. Average feed intake, ADG, and feed conversion ratio (FCR) were calculated for each pen and diet treatment. In addition, disease symptoms such as diarrhea were recorded daily during the experiment.

\section{Digestibility}

For apparent total tract digestibility (ATTD), fresh fecal samples catched immediately after emission from all of the pigs were collected per pen 2 times/day (100 g/pig) for the past 5 days of the experiment and stored $-20^{\circ} \mathrm{C}$. At the end of the collection, the fecal samples were thawed, mixed, and pooled per pen, after which they were dried and analyzed for ATTD determination. The ATTD of nutrients was calculated using the following equation [27]:

$$
\begin{gathered}
\text { Nutrient digestibility } \\
(\% \text { of intake })
\end{gathered}=\left(\begin{array}{c}
C r 2 O 3(\text { diet }) \times \\
1-\frac{\text { nutrient }(\text { faces })}{C r 2 O 3(\text { faces }) \times} \\
\text { nutrient }(\text { diet })
\end{array}\right) \times 100
$$

Where, nutrient digestibility is apparent digestibility of a nutrient or energy in the diet (\%); nutrient (diet) is a nutrient (g) or gross energy (GE) (kcal) content per $\mathrm{kg} \mathrm{DM}$ in diet and feces samples; and $\mathrm{Cr}_{2} \mathrm{O}_{3}$ (diet) and $\mathrm{Cr}_{2} \mathrm{O}_{3}$ (feces) are $\mathrm{Cr}_{2} \mathrm{O}_{3}$ content (g/kg DM) in diet and feces samples, respectively.

\section{Blood and serum parameters}

At the end of the experiment, 24 pigs (six pigs per treatment, one male and one female in each pen) were 
Table-1: Ingredients and nutrient composition of the experimental diets.

\begin{tabular}{|c|c|c|c|c|c|}
\hline \multirow[t]{2}{*}{ Items } & \multicolumn{4}{|c|}{ Dietary treatment ${ }^{1}$} & \multirow[t]{2}{*}{ MP } \\
\hline & TO & T1 & T2 & T3 & \\
\hline \multicolumn{6}{|l|}{$\begin{array}{l}\text { Ingredients (\%, } \\
\text { as-fed basis) }\end{array}$} \\
\hline Corn & 33.9 & 33.2 & 32.6 & 31.9 & \\
\hline Soybean meal & 13.4 & 13.1 & 12.8 & 12.5 & \\
\hline Fish meal & 3.50 & 3.40 & 3.30 & 3.20 & \\
\hline Rice bran & 25.0 & 24.5 & 24.0 & 23.5 & \\
\hline Wheat bran & 20.0 & 19.6 & 19.2 & 18.8 & \\
\hline Limestone & 1.50 & 1.50 & 1.40 & 1.40 & \\
\hline $\begin{array}{l}\text { Vitamin-mineral } \\
\text { premix }^{2}\end{array}$ & 0.50 & 0.50 & 0.50 & 0.50 & \\
\hline Salt & 1.00 & 1.00 & 1.00 & 1.00 & \\
\hline Farm enzyme ${ }^{3}$ & 0.50 & 0.50 & 0.50 & 0.50 & \\
\hline L-lysine $\mathrm{HCl}, 98.5 \%$ & 0.50 & 0.50 & 0.50 & 0.50 & \\
\hline DL-Methionine, $98 \%$ & 0.20 & 0.20 & 0.20 & 0.20 & \\
\hline $\begin{array}{l}\text { Medicinal plants } \\
\text { powder }^{4}\end{array}$ & - & 2.0 & 4.0 & 6.0 & \\
\hline \multicolumn{6}{|l|}{$\begin{array}{l}\text { Analyzed composition } \\
(\% \mathrm{DM}) \text { and energy } \\
\text { value }(\mathrm{MJ} / \mathrm{kg} \mathrm{DM})\end{array}$} \\
\hline Dry matter & 88.9 & 88.4 & 89.1 & 89.2 & 92.4 \\
\hline Crude protein & 18.8 & 18.8 & 18.7 & 18.7 & 12.7 \\
\hline Ether extract & 7.55 & 7.22 & 7.26 & 7.30 & 1.63 \\
\hline Ash & 8.86 & 8.73 & 8.80 & 8.86 & 12.3 \\
\hline Crude fiber & 5.24 & 5.89 & 5.97 & 6.95 & 28.4 \\
\hline Calcium & 1.39 & 1.11 & 1.21 & 1.18 & 1.32 \\
\hline Total phosphorus & 0.85 & 0.79 & 0.86 & 0.86 & 0.34 \\
\hline $\begin{array}{l}\text { Gross energy } \\
(\mathrm{MJ} / \mathrm{kg} \mathrm{DM})\end{array}$ & 18.5 & 18.5 & 18.2 & 18.5 & 18.3 \\
\hline $\begin{array}{l}\text { Metabolizable } \\
\text { energy }^{5}(\mathrm{MJ} / \mathrm{kg} \mathrm{DM})\end{array}$ & 13.9 & 13.8 & 13.7 & 13.5 & - \\
\hline Lysine $^{6}$ & 1.33 & 1.32 & 1.31 & 1.30 & - \\
\hline Methionine ${ }^{6}$ & 0.54 & 0.53 & 0.53 & 0.53 & - \\
\hline
\end{tabular}

$\mathrm{MP}=$ Medicinal plants power. ${ }^{1} \mathrm{~T} 0=$ Control diet; $\mathrm{T} 2, \mathrm{~T} 4$, and T6: T0 supplemented with 2, 4, and 6\% of MP, respectively. ${ }^{2}$ Premix in $1 \mathrm{~kg}: \mathrm{ZnSO}_{4}$

(min-max): 250-300 mg; $\mathrm{FeSO}_{4}$ (min-max): 150-200

$\mathrm{mg} ; \mathrm{MnSO}_{4}$ (min-max): 150-200 mg; CuSO

(min-max): 250-300 mg; Biotin: 8 mg; activity

enzyme: $100 \mathrm{~g}$; coarse sand $(\max ): 2 \%$; sufficient

carrier for $1000 \mathrm{~g}$; moisture (max): 10\%. ${ }^{3}$ Enzyme

in $1 \mathrm{~kg}$ : Saccharomyces boulardii: $10^{9}-2.10^{10} \mathrm{CFU} / \mathrm{g}$,

Saccharomycopsis fibuligera: $10^{6}-10^{10} \mathrm{CFU} / \mathrm{g}$,

Lactobacillus acidophilus: $10^{9}-3.10^{9} \mathrm{CFU} / \mathrm{g}$, Candida

tropicalis: $10^{5}-10^{8} \mathrm{CFU} / \mathrm{g}$, moisture (max): $10 \% .{ }^{4} \mathrm{~A}$ blend

powder of medicinal plants in $1 \mathrm{~kg}: 60 \%$

B. pilosa, $15 \%$ U. lobata, $15 \%$ P. palatiferum, 5\%

Ramulus cinnamomi, and $5 \%$ Star anise. ${ }^{5}$ Calculated data according to the equation of [25] for $\mathrm{ME}$

estimation: $\mathrm{ME}=4168-12.3 \times \mathrm{Ash}+1.4 \times \mathrm{CP}+4.1 \times \mathrm{EE}-$

$6.1 \times \mathrm{CF}(\mathrm{g} / \mathrm{kg} \mathrm{DM}) .{ }^{6} \mathrm{Calculated}$ data.

randomly chosen for blood sampling through the jugular vein using a sterile needle. The blood from each pig was collected into both K2EDTA $(3 \mathrm{~mL})$ and serum tubes ( $5 \mathrm{~mL}$ ) (Zhejiang Gongdong Medical Technology Co. Ltd., Zhejiang, China). The blood samples in EDTA tubes were automatically analyzed using hematology analyzer ABX Pentra DX 120c to measure red blood cell (RBC) and white blood cell (WBC) counts, hemoglobin $(\mathrm{Hb})$ concentration, and lymphocytes (WBC) percentage. The blood serum tubes were centrifuged at $3000 \mathrm{rpm}$ for $15 \mathrm{~min}$, and then, clean serum was collected to determine concentration levels of AST,
ALT, bilirubin, total cholesterol, creatinine, high-density lipoprotein (HDL), low-density lipoprotein (LDL), protein, and urea using Cobas 8000 modular analyzer series (Roche-Hitachi, Tokyo, Japan).

\section{Fecal microbiota}

On day 28 of the experiment, fecal samples (about $50 \mathrm{~g}$ ) of one male and one female per pen were collected directly from rectum, transferred to sterile falcons, and immediately placed on ice in an insulation box for a maximum of $1 \mathrm{~h}$ transportation to the laboratory for further analysis. At the laboratory level, $0.01 \mathrm{~g}$ of fresh fecal sample of each animal was taken and placed into Eppendorf tubes supplemented with $990 \mu \mathrm{L} 1 \times$ phosphate-buffered saline and 6-fold dilutions were prepared. The samples were plated on agar plates. Bacteria were quantified based on colony-forming units (cfu) counting on the culturing plates $\left(\log 10 \mathrm{cfu} \mathrm{g}^{-1}\right)$. E. coli were enumerated on eosin methylene blue agar (Merck, Germany) after aerobic incubation at $37^{\circ} \mathrm{C}$ for 1 day. Salmonella species were enumerated on xylose lysine deoxycholate agar (Merck, Germany) after aerobic incubation at $37^{\circ} \mathrm{C}$ for 1 day. Clostridium perfringens were enumerated on Tryptose Sulfite Cycloserine agar (Merck, Germany) after anaerobic incubation at $37^{\circ} \mathrm{C}$ for 1 day. Total anaerobic bacteria were enumerated on nutrient agar (Merck, Germany) after anaerobic incubation at $37^{\circ} \mathrm{C}$ for $1-2$ days. Before statistical analysis, fecal microbiota concentrations were transformed $(\log )$.

\section{Chemical analysis}

Diets and feces samples were pre-dried by oven drying at $65^{\circ} \mathrm{C}$ for $72 \mathrm{~h}$ and then milled separately through a $1 \mathrm{~mm}$ screen before analysis. Diets and feces were analyzed for crude protein (CP); method 954.01 [28], ether extract (EE) with petroleum ether solvent (method 920.39 [28]), ash (method 942.05 [28]), crude fiber (CF; method 962.09 [28], neutral detergent fiber (NDF) with fiber filter bags of Ankom Technology F57 (method 973.18 [28]), GE through bomb calorimeter E2K (Germany), and chromium concentration was analyzed using ultraviolet absorption spectrophotometry (DR 3000, Germany) as previously described [29].

\section{Statistical analysis}

All data were analyzed using the PROC MIXED procedure of SAS (version 9.4, Institute Inc., Cary, NC, USA), and each pen was used as an experimental unit. The statistical model included the diets $(n=4)$ as a fixed effect and the blocks $(n=3)$ as random effects. Pen was used as an experimental unit for growth performance and digestibility data, and individual pig as an experimental unit for fecal microbiota, and blood profiles. For repeated measures performed on the same experimental unit, a similar model was used but including the effect of a compound symmetry structure of covariance. Orthogonal polynomials were 
performed to determine linear and quadratic effects of increasing levels of MP in diets [30]. Data for pigs fed diets containing MP were compared with data for pigs fed control diet using orthogonal contrasts. The multiple comparisons of least-square means were performed according to Tukey adjustment. Significance was defined as $p<0.05$ and $0.05<p<0.10$ were considered as a trend.

\section{Results}

\section{Animal performance, health, and digestibility}

The performances of the experimental pigs are shown in Table-2. There were no animal losses during the experimental period in the present study and no episodes of diarrhea or other symptoms were observed in the different groups. The IBW was not significantly different between dietary treatments and there were no significant effects between groups on FBW, ADFI, and FCR (Table-2). Effects of increasing levels of MP on ATTD are presented in Table-3. No significant differences in the ATTD of DM, OM, CP, EE, and GE were observed between diet groups.

\section{Blood characteristics}

Significant linear decreases in $\mathrm{RBC}(\mathrm{p}=0.003)$, and plasma cholesterol, LDL, and urea nitrogen $(p \leq 0.04)$ were observed in pigs fed MP diets compared with those fed the control diet. A trend for a linear decrease in lymphocytes proportions $(p=0.05)$ and a trend for open-up quadratic effect $(p \leq 0.08)$ on creatinine and total protein concentrations were observed between diet groups. The other blood parameters including WBC, $\mathrm{Hb}, \mathrm{AST}$, ALT, bilirubin, or HDL were unaffected by the dietary treatments (Table-4). Besides, using orthogonal contrasts, decrease in RBC $(\mathrm{p}<0.05)$, decrease trend in plasma cholesterol, and

Table-2: Feed intake, average daily gain, and feed conversion ratio (LSM) of growing pigs fed diets containing different levels of medicinal plants powder.

\begin{tabular}{|c|c|c|c|c|c|c|c|}
\hline \multirow[t]{2}{*}{ Items } & \multicolumn{4}{|c|}{ Dietary treatment ${ }^{1}$} & \multirow[t]{2}{*}{ SEM } & \multicolumn{2}{|c|}{ p-value } \\
\hline & TO & T1 & T2 & T3 & & Linear & Quadratic \\
\hline $\mathrm{n}$ & 12 & 12 & 12 & 12 & & & \\
\hline $\begin{array}{l}\text { IBW } \\
(\mathrm{kg})\end{array}$ & 30.3 & 30.4 & 30.3 & 30.3 & 0.42 & 0.93 & 1.00 \\
\hline $\begin{array}{l}\text { FBW } \\
\text { (kg) }\end{array}$ & 65.6 & 65.1 & 64.6 & 64.2 & 1.49 & 0.48 & 0.98 \\
\hline $\begin{array}{l}\text { ADFI } \\
(\mathrm{kg} / \mathrm{d})\end{array}$ & 1.84 & 1.86 & 1.83 & 1.80 & 0.04 & 0.37 & 0.56 \\
\hline $\begin{array}{l}\text { ADG } \\
(\mathrm{g} / \mathrm{d})\end{array}$ & 750 & 737 & 731 & 720 & 31.8 & 0.50 & 0.98 \\
\hline $\begin{array}{l}\text { FCR } \\
(\mathrm{kg} / \\
\mathrm{kg})\end{array}$ & 2.46 & 2.53 & 2.51 & 2.50 & 0.06 & 0.64 & 0.53 \\
\hline
\end{tabular}

LSM=Least squares mean; SEM=Standard error of the mean; $\mathrm{n}=$ Number of animals; $\mathrm{d}=$ Day; $\mathrm{g}=$

Gram; IBW=Initial body weight; $F B W=$ Final body weight; $A D G=$ Average daily gain; $A D F I=$ Average daily feed intake; $F C R=$ Feed conversion ratio ( $\mathrm{kg}$ feed/kg gain). ${ }^{1} \mathrm{~T} 0=$ Control diet; $\mathrm{T} 1, \mathrm{~T} 2$, and $\mathrm{T} 3$ supplemented with 2,4 , and $6 \%$ of blend powder of medicinal plants.
LDL $(\mathrm{p} \leq 0.09)$ were observed when animals fed MP diets were compared with the control animals.

\section{Fecal microbiota}

Fecal E. coli, Salmonella, Clostridium, and total bacteria concentrations were not significantly altered ( $>0.05$ ) by the treatments (Table-5).

\section{Discussion}

In the present study, feeding increasing levels of MP to growing pigs had no significant effect on FBW, ADG, ADFI, and FCR. In agreement with our results, Hanczakowska et al. [31] reported that a diet containing herbal extract mixture of Salvia officinalis, Urtica dioica, Magnolia officinalis, and Echinacea purpurea unaffected the growth performance of pigs when compared to those fed a control diet. Ahmed et al. [32] reported that growing-finishing pigs fed a diet containing medicinal plants (pomegranate, Ginkgo biloba, and licorice) showed no changes in live body weight and ADG compared to a control group. Utiyama et al. [33] reported a similar ADG in weanling pigs fed a diet with medicinal extract (garlic, clove, cinnamon, pepper, thyme, cinnamaldehyde, and eugenol) compared to a control group. However, Yan et al. [34] demonstrated that growing pigs fed a diet supplemented with the inclusion of medicinal extract (buckwheat, thyme, curcuma, black pepper, and ginger) had improved ADG and ADFI but not FCR. Marcin et al. [35] reported that piglets fed a diet supplemented with extracts of sage and oregano also had significantly improved ADG. The world of phytochemistry being vast, the contradictory results regarding growth performance responses to natural, dried, or extracted herbs may be easily ascribed to different species, plant parts and their physical properties, age of plant, harvest time, processing method, and different dosage used $[6,36,37]$. Secondarily, different physiological periods of animal and housing conditions may respond differently to herb supplementation $[6,31]$. ATTD of nutrients was similar in pigs fed MP diets compared with those fed the control diet during 7 experimental weeks. Similar results were observed in the previous experiment [38] who reported that nutrient digestibility of growing pigs fed diet with herbal flavor supplementation for 10 experimental weeks was not affected. This suggests that the digestibility of moderate amounts of herbal plants could be similar to that of a control diet.

Dietary supplementation with medicinal plants may have a beneficial effect on hematological and biochemical characteristics of pigs. Supplementation with fermented medicinal plants (Gynura procumbens, Rehmannia glutinosa, and Scutellaria baicalensis) increased WBC concentration in growing pigs [39]. Increase in RBC counts and blood lymphocytes concentrations was found in weaning pigs fed a diet supplemented with fermented garlic powder at 0.5 , 
Table-3: Apparent total tract digestibility (LSM) of growing pigs fed diets containing different levels of medicinal plants powder (\%).

\begin{tabular}{|c|c|c|c|c|c|c|c|}
\hline \multirow[t]{2}{*}{ Items } & \multicolumn{4}{|c|}{ Dietary treatment ${ }^{1}$} & \multirow[t]{2}{*}{ SEM } & \multicolumn{2}{|c|}{ p-value } \\
\hline & TO & T1 & T2 & T3 & & Linear & Quadratic \\
\hline DM & 92.49 & 92.61 & 91.56 & 92.44 & 0.40 & 0.79 & 0.90 \\
\hline OM & 79.15 & 78.29 & 77.91 & 77.20 & 1.01 & 0.69 & 0.28 \\
\hline $\mathrm{CP}$ & 80.88 & 79.71 & 78.68 & 78.43 & 1.07 & 0.51 & 0.14 \\
\hline EE & 72.51 & 70.02 & 70.47 & 71.52 & 2.49 & 0.47 & 0.92 \\
\hline GE & 77.99 & 75.46 & 76.90 & 76.29 & 1.19 & 0.22 & 0.92 \\
\hline
\end{tabular}

LSM=Least squares mean; SEM=Standard error of the mean. ${ }^{1}$ T0, control diet; T1, T2, and T3 supplemented with 2,4 , and $6 \%$ of blend powder of medicinal plants. $\mathrm{DM}=$ Dry matter; $\mathrm{OM}=$ Organic matter; $\mathrm{CP}=\mathrm{Crude}$ protein; $\mathrm{EE}=\mathrm{Ether}$ extract; GE=Gross energy.

Table-4: Blood parameters (LSM) of growing pigs fed diets containing different levels of medicinal plant powders.

\begin{tabular}{|c|c|c|c|c|c|c|c|}
\hline \multirow[t]{2}{*}{ Items } & \multicolumn{4}{|c|}{ Dietary treatment ${ }^{1}$} & \multirow[t]{2}{*}{ SEM } & \multicolumn{2}{|c|}{ p-value } \\
\hline & TO & $\mathbf{T 1}$ & $\mathbf{T 2}$ & T3 & & Linear & Quadratic \\
\hline $\begin{array}{l}\text { Number of } \\
\text { animals }\end{array}$ & 6 & 6 & 6 & 6 & & & \\
\hline $\begin{array}{l}\text { WBC } \\
(G / L)\end{array}$ & 27.0 & 24.4 & 22.0 & 26.7 & 2.28 & 0.76 & 0.15 \\
\hline $\mathrm{RBC}(\mathrm{T} / \mathrm{L})$ & 7.60 & 6.92 & 6.92 & 6.62 & 0.16 & 0.003 & 0.26 \\
\hline $\mathrm{Hb}(\mathrm{g} / \mathrm{dL})$ & 12.4 & 11.9 & 11.5 & 11.2 & 0.59 & 0.17 & 0.85 \\
\hline LYM (\%) & 69.5 & 58.8 & 60.6 & 52.0 & 4.97 & 0.05 & 0.84 \\
\hline AST (U/L) & 37.7 & 57.9 & 37.9 & 43.1 & 8.63 & 0.92 & 0.40 \\
\hline $\operatorname{ALT}(\mathrm{U} / \mathrm{L})$ & 51.7 & 61.2 & 54.0 & 65.7 & 4.61 & 0.12 & 0.82 \\
\hline $\begin{array}{l}\text { Bilirubin } \\
(\mu \mathrm{mol} / \mathrm{L})\end{array}$ & 1.75 & 0.50 & 0.60 & 0.75 & 0.58 & 0.28 & 0.25 \\
\hline $\begin{array}{l}\text { Creatinine } \\
(\mu \mathrm{mol} / \mathrm{L})\end{array}$ & 137 & 117 & 118 & 134 & 9.63 & 0.88 & 0.08 \\
\hline $\begin{array}{l}\text { Total } \\
\text { cholesterol } \\
\text { (mmol/L) }\end{array}$ & 2.37 & 2.16 & 2.06 & 1.91 & 0.10 & 0.01 & 0.77 \\
\hline $\begin{array}{l}\text { HDL } \\
(\mathrm{mmol} / \mathrm{L})\end{array}$ & 0.97 & 1.04 & 0.99 & 0.98 & 0.03 & 0.97 & 0.22 \\
\hline $\begin{array}{l}\text { LDL } \\
\text { (mmol/L) }\end{array}$ & 1.09 & 0.98 & 0.86 & 0.77 & 0.08 & 0.02 & 0.92 \\
\hline $\begin{array}{l}\text { Total } \\
\text { protein } \\
(\mathrm{g} / \mathrm{L})\end{array}$ & 70.4 & 66.0 & 66.7 & 68.5 & 1.42 & 0.44 & 0.05 \\
\hline $\begin{array}{l}\text { Urea } \\
\text { nitrogen } \\
(\mathrm{mmol} / \mathrm{L})\end{array}$ & 3.91 & 3.90 & 3.13 & 2.90 & 0.37 & 0.04 & 0.77 \\
\hline
\end{tabular}

LSM=Least squares mean; SEM=Standard error of the mean; $\mathrm{WBC}=$ White blood cell count; $\mathrm{RBC}=$ Red blood cell count; $\mathrm{Hb}=$ Hemoglobin; LYM=

Lymphocyte; AST=Aspartate aminotransferase; $\mathrm{ALT}=$ Alanine aminotransferase; $\mathrm{HDL}=\mathrm{High}$-density lipoprotein; LDL=Low-density lipoprotein. ${ }^{1} \mathrm{TO}$, control diet; $\mathrm{T} 1, \mathrm{~T} 2$, and $\mathrm{T} 3$ supplemented with 2,4 , and $6 \%$ of blend powder of medicinal plants.

1 , and $2 \mathrm{~g} / \mathrm{kg}$ feed [40]. Diets supplemented with herb extract mixture (buckwheat, thyme, curcuma, black pepper, and ginger) at $250 \mathrm{mg}$ and $500 \mathrm{mg} / \mathrm{kg}$ feed increased significantly WBC and RBC counts and blood lymphocytes concentrations compared with the control diet at end of the experiment [34]. In the current work, no significant differences on $\mathrm{WBC}, \mathrm{Hb}$, and lymphocytes - but a trend - concentrations were observed in pigs fed MP diets compared with those fed the control diet. However, a significant decrease in RBC count was observed in pigs fed MP diet compared to pigs fed the control diet. This could be due to the probable presence of high polyphenol content in MP which is known to cause hemolysis of RBC [41]. Despite this decreased RBC count with inclusion of MP, hematological indicators were found to be within normal ranges for growing pigs, as reported previously $[42,43]$. On the other hand, pigs fed MP diet had significantly lower total cholesterol, LDL, and urea nitrogen than those from the control diet. Plant polyphenols markedly enhance cholesterol secretion into bile [44], which, in conjunction with the unabsorbed cholesterol, results in increased fecal excretion of cholesterol without affecting the excretion of bile acids, and plant polyphenols intake lowers, therefore, plasma cholesterol levels in animals. Dietary supplementation of an herbal plants combination in natural form (pomegranate, G. biloba, and licorice) decreased serum cholesterol level [32]. Thus, in our study, a decrease in serum total cholesterol level can be due to the probable presence of polyphenol in MP diets. On the other hand, flavonoids, which are reported to be present in the medicinal plant presently used, reduced cholesterol biosynthesis due to inhibition hepatic 3-hydroxy-3-methyl-glutaryl-CoA reductase and acyl CoA: cholesterol O-acyltransferase [45]. Lower plasma cholesterol levels observed in the present experiment could thus be due to the conjunction of the two above phenomenon. In addition, lower serum urea content was observed in pigs fed MP diets compared with those fed the control diet. A previous study [34] reported that growing pigs fed diet with herbal plants decreased $\mathrm{NH}_{3}$ and $\mathrm{H}_{2} \mathrm{~S}$ concentrations of feces compared with those fed the control diet. Thus, MP could have promoted urea translocation from blood to intestine lumen, especially due to higher crude fiber content in the experimental diets. However, this hypothesis must be confirmed.

In our study, MP diets did not inhibit in pig feces the counts of the pathogenic bacteria studied compared with the control diet, which is consistent with a variety of medicinal plants as reported previously [46] who indicated that herbal plants did not inhibit the growth of E. coli and even enhance bacteria 
Table-5: Fecal microbial shedding (LSM) of growing pigs fed diets containing different levels of medicinal plant powders ( $\log \mathrm{CFU} / \mathrm{g}$ of wet feces).

\begin{tabular}{|c|c|c|c|c|c|c|c|}
\hline \multirow[t]{2}{*}{ Items } & \multicolumn{4}{|c|}{ Dietary treatment ${ }^{1}$} & \multirow[t]{2}{*}{ SEM } & \multicolumn{2}{|c|}{ p-value } \\
\hline & TO & T1 & $\mathbf{T 2}$ & T3 & & Linear & Quadratic \\
\hline Number of animals & 6 & 6 & 6 & 6 & & & \\
\hline Escherichia coli & 6.15 & 6.14 & 6.07 & 6.19 & 0.20 & 0.97 & 0.76 \\
\hline Salmonella & 2.13 & 2.05 & 2.15 & 4.13 & 0.95 & 0.98 & 0.97 \\
\hline Clostridium & 1.30 & 0.00 & 1.78 & 0.00 & 0.58 & 0.22 & 0.63 \\
\hline Total bacteria & 8.10 & 8.31 & 7.85 & 7.94 & 0.25 & 0.30 & 0.63 \\
\hline
\end{tabular}

LSM=Least squares mean; SEM=Standard error of the mean. ${ }^{1} \mathrm{~T} 0$, control diet; T1, T2, and T3 supplemented with

2,4 , and $6 \%$ of blend powder of medicinal plants.

growth in gut intestinal of animals. Similarly, no significant differences in intestinal microbiology and diarrhea occurrence were observed in weanling pigs fed a diet with herbal extract mixture (garlic, clove, cinnamon, pepper, thyme, cinnamaldehyde, and eugenol) compared to those fed a control diet [33]. The present results indicate that the plant mixture did not show any bacteria modulating effect in gut on growing pigs.

\section{Conclusion}

From the present study, it can be concluded that growing pig diets containing up to $60 \mathrm{~g} / \mathrm{kg}$ of a blended power of medicinal plants (B. pilosa, U. lobata, P. palatiferum, R. cinnamomi, and Star anise) reduced blood cholesterol, LDL, and urea nitrogen concentrations without influencing performance, nutrient digestibility, and fecal microbiota of growing pigs. A limitation of this study is lacking interaction tests among medicinal plants. Further studies should be performed to obtain more comprehensive results.

\section{Authors' Contributions}

NCO, VDT, and HJ: Conceived and designed research. NCO and NDT: Conducted the experiment and collected samples. NCO and TQL: Analyzed the samples. NCO and HJ: Analyzed the data. NCO: Wrote original draft. All authors read and approved the final manuscript.

\section{Acknowledgments}

We would like to thank the Department of Animal Genetics and Breeding and Central Laboratory, Faculty of Animal Science; Key Laboratory for Veterinary Biotechnology, Faculty of Veterinary Medicine, Vietnam National University of Agriculture for the supports. We also thank ARES-CCD (Académie de Recherche et d'Enseignement Supérieur, fédération des établissements d'enseignement supérieur de la Fédération Wallonie-Bruxelles, Belgique) and Department of Sciences and Technology, Hai Duong province, Vietnam, for financial support for the study (Grant no.T2020-02-04VB and NN.15.HVNN.20-21).

\section{Competing Interests}

The authors declare that they have no competing interests.

\section{Publisher's Note}

Veterinary World remains neutral with regard to jurisdictional claims in published institutional affiliation.

\section{References}

1. Suthathip, T., Sunpetch, A. and Rungtip, C. (2016) Occurrence and molecular characteristics of antimicrobial resistance of Escherichia coli from broilers, pigs and meat products in Thailand and Cambodia Provinces. Microbiol. Immunol., 60(9): 575-585.

2. Hashemi, S.R. and Davoodi, H. (2011) Herbal plants and their derivatives as growth and health promoters in animal nutrition. Vet. Res. Commun., 35(3): 169-180.

3. Kumar, A.K. (2018) Effect of Sargassum wightii on growth, carcass and serum qualities of broiler chickens. Open Access J. Vet. Sci. Res., 3(2): 1-10.

4. Omonkhua, A.A. and Onoagbe, I.O. (2011) Evaluation of the long term effects of Urena lobata root extracts on blood glucose and hepatic function of normal rabbits. Toxicol. Environ. Health Sci., 3(8): 204-213.

5. Rehman, Z. and Munir, M.T. (2015) Effect of garlic on the health and performance of broilers. Veterinaria, 3(1): 32-39.

6. Lei, X.J., Yun, H.M. and Kim, I.H. (2018) Effects of dietary supplementation of natural and fermented herbs on growth performance, nutrient digestibility, blood parameters, meat quality and fatty acid composition in growing-finishing pigs. Ital. J. Anim. Sci., 17(4): 984-993.

7. Namkung, H., Li, J., Gong, M., Yu, H., Cottrill, M. and de Lange, C.F.M. (2004) Impact of feeding blends of organic acids and herbal extracts on growth performance, gut microbiota and digestive function in newly weaned pigs. Can. $J$. Anim. Sci., 84: 697-704.

8. Matysiak, B., Jacyno, E., Kawecka, M., Kołodziej-Skalska, A. and Pietruszka, A. (2012) The effect of plant extracts fed before farrowing and during lactation on sow and piglet performance. S. Afr. J. Anim. Sci., 42(1): 15-21.

9. Alikwe, P.C.N., Ohimain, E.I. and Omotosho, S.M. (2014) Evaluation of the proximate, mineral, phytochemical, and amino acid composition of Bidens pilosa as potential feed/ feed additive for non-ruminant livestock. Anim. Vet. Sci., 2(2): 18-21.

10. Bernard, D., Kwabena, A.I., Osei, O.D., Daniel, G.A., Elom, S.A. and Sandra, A. (2014) The effect of different drying methods on the phytochemicals and radical scavenging activity of Ceylon cinnamon (Cinnamomum zeylanicum) plant parts. Eur. J. Med. Plants, 4(11): 1324-1335.

11. Ho, T.C. and Chun, B.S. (2019) Extraction of bioactive compounds from Pseuderanthemum palatiferum (Nees) Radlk. Using subcritical water and conventional solvents: A comparison study. J. Food Sci., 84(5): 1201-1207.

12. Patra, J.K., Das, G., Bose, S., Banerjee, S., Chethala, N.V., Rodríguez-Torres, M.D.P. and Shin, H. (2020) Star anise (Illicium verum): Chemical compounds, antiviral properties, 
and clinical relevance. Phytother. Res., 34(6): 1248-1267.

13. Shaba, A.N. (2017) Nutritional assessment of Urena lobata leaves. FUW Trends Sci. Technol. J., 2(1A): 220-222.

14. National Academies Press. (1989) Recommended Dietary Allowances. $10^{\text {th }}$ ed. National Academies Press, US, Washington, DC.

15. Babu, S.S., Madhuri, D.B. and Ali, S.L. (2016) A pharmacological review of Urena lobata plant. Asian J. Pharm. Clin. Res., 9(2): 20-22.

16. Liu, J., Zhang, Q., Li, R.L., Wei, S.J., Huang, C.Y., Gao, Y.X. and Pu, X.F. (2020) The traditional uses, phytochemistry, pharmacology and toxicology of Cinnamomi ramulus: A review. J. Pharm. Pharmacol., 72(3): 319-342.

17. Nguyen, Q.V. and Eun, J.B. (2011) Antioxidant activity of solvent extracts from Vietnamese medicinal plants. J. Med. Plants Res., 5(13): 2798-2811.

18. Xuan, T.D. and Khanh, T.D. (2016) Chemistry and pharmacology of Bidens pilosa: An overview. J. Pharm. Investig., 46(2): 91-132.

19. Vuong, P.V. (2014) Study on the Chemical Constituents and Bioactive Compounds of Bidens pilosa L. Doctoral Thesis. Institute of Medicinal Materials, Hanoi, Vietnam.

20. Rojas, J.J., Ochoa, V.J., Ocampo, S.A. and Muñoz, J.F. (2006) Screening for antimicrobial activity of ten medicinal plants used in Colombian folkloric medicine: A possible alternative in the treatment of non-nosocomial infections. BMC Complement. Altern. Med., 6(2): 1-6.

21. Dieu, H.K., Loc, C.B., Yamasaki, S. and Hirata, Y. (2006) The effects of Pseuderanthemum palatiferum, a new medicinal plant, on growth performances and diarrhea of piglets. Jpn. Agric. Res. Q., 40(1): 85-91.

22. Shahrajabian, M.H., Sun, W. and Cheng, Q. (2020) Chinese star anise (Illicium verum) and pyrethrum (Chrysanthemum cinerariifolium) as natural alternatives for organic farming and health care a review. Aust. J. Crop Sci., 14(3): 517-523.

23. Tian, L., Huang, H., Ye, X., Li, N., Zou, T., Zhou, A. and Liu, Y. (2012) Anti-influenza virus activity and chemical composition of Ramulus cinnamomi-Ramulus zingiber recens, a Chinese herb pair. Chin. J. Hosp. Pharm., 2012: 14.

24. Charal, J.W., Bidner, T.D., Southern, L.L. and Lavergne, T.A. (2016) Effect of anise oil fed to lactating sows and nursery pigs on sow feed intake, piglet performance, and weanling pig feed intake and growth performance. Prof. Anim. Sci., 32(1): 99-105.

25. Noblet, J. and Perez, J.M. (1993) Prediction of digestibility of nutrients and energy values of pig diets from chemical analysis. J. Anim. Sci., 71(12): 3389-3398.

26. National Academies Press. (2012) Nutrient Requirements of Swine. National Academies Press, Washington, DC, USA.

27. Serena, A., Jørgensen, H. and Knudsen, K.E.B. (2008) Digestion of carbohydrates and utilization of energy in sows fed diets with contrasting levels and physicochemical properties of dietary fiber. J. Anim. Sci., 86(9): 2208-2216.

28. Association of Official Analytical Chemists. (1990) Official Methods of Analysis. 15 $5^{\text {th }}$ ed. Association of Official Analytical Chemists, Arlington, VA, USA.

29. Williams, C.H., David, D.J. and Iismaa, O. (1962) The determination of chromic oxide in faeces samples by atomic absorption spectrophotometry. J. Agric. Sci., 59(3): 381-385.

30. Widmer, M.R., McGinnis, L.M., Wulf, D.M. and Stein, H.H. (2008) Effects of feeding distillers dried grains with solubles, high-protein distillers dried grains, and corn germ to growing-finishing pigs on pig performance, carcass quality, and the palatability of pork. J. Anim. Sci., 86(8): 1819-1831.

31. Hanczakowska, E., Świątkiewicz, M. and Grela, E.R. (2015) Effect of dietary inclusion of a herbal extract mixture and different oils on pig performance and meat quality. Meat Sci., 108: 61-66.

32. Ahmed, S.T., Mun, H.S., Islam, M.M., Ko, S.Y. and Yang, C.J. (2016) Effects of dietary natural and fermented herb combination on growth performance, carcass traits and meat quality in grower-finisher pigs. Meat Sci., 122: 7-15.

33. Utiyama, C.E., Oetting, L.L., Giani, P.A., dos Santos Ruiz, U. and Miyada, V.S. (2006) Effect of antimicrobials, prebiotics, probiotics and herbal extracts on intestinal microbiology, diarrhea incidence and performance of weanling pigs. Rev. Bras. Zootec., 35(6): 2359-2367.

34. Yan, L., Meng, Q.W. and Kim, I.H. (2011) The effect of an herb extract mixture on growth performance, nutrient digestibility, blood characteristics and fecal noxious gas content in growing pigs. Livest. Sci., 141(2-3): 143-147.

35. Marcin, A., Lauková, A. and Mati, R. (2006) Comparison of the effects of Enterococcus faecium and aromatic oils from sage and oregano on growth performance and diarrhoeal diseases of weaned pigs. Biologia (Bratisl), 61(6): 789-795.

36. Hashemi, S.R. and Davoodi, H. (2010) Phytogenics as a new class of feed additive in poultry industry. J. Anim. Vet. $A d v ., 9(17):$ 2295-2304

37. Wenk, C. (2003) Herbs and botanicals as feed additives in monogastric animals. Asian Australas. J. Anim. Sci., 16(2): 282-289.

38. Ao, X., Lei, Y. and Kim, I.H. (2020) Effect of flavor supplementation on growth performance, nutrient digestibility, blood profiles, and carcass quality in growing-finishing pigs. Can. J. Anim. Sci., 100(1): 133-139.

39. Jeong, J.S. and Kim, I.H. (2015) Effect of probiotic bacteria-fermented medicinal plants (Gynura procumbens, Rehmannia glutinosa, Scutellaria baicalensis) as performance enhancers in growing pigs. Anim. Sci. J., 86(6): 603-609.

40. Yan, L. and Kim, I.H. (2013) Effects of dietary supplementation of fermented garlic powder on growth performance, apparent total tract digestibility, blood characteristics and faecal microbial concentration in weanling pigs. J. Anim. Physiol. Anim. Nutr., 97(3): 457-464.

41. Olufemi, B.E., Assiak, I.E., Ayoadi, G.O. and Onigemo, M.A. (2003) Studies on effects of Amaranthus spinosus leaf extract on the haematology of growing pigs. Afr. J. Biomed. Res., 6(3): 54045.

42. Clark, S.G. and Coffer, N. (2008) Normal hematology and hematologic disorders in potbellied pigs. Vet. Clin. North Am. Exot. Anim. Pract., 11(3): 569-582.

43. Thorn, C.E. (2010) Hematology of the pig. In: Shalm's Veterinary Hematology. Wiley-Blackwell, Hoboken, New Jersey. p843-851.

44. Agarwal, V.K. (2012) Bioactive constituents of medicinal plants. In: The Modern Ayurveda: Milestones Beyond the Classical Age. CRC Press, New York. p204-205.

45. Bok, S.H., Lee, S.H., Park, Y.B., Bae, K.H., Son, K.H., Jeong, T.S. and Choi, M.S. (1999) Plasma and hepatic cholesterol and hepatic activities of 3-hydroxy-3-methyl-glutaryl-CoA reductase and Acyl CoA: Cholesterol transferase is lower in rats fed citrus peel extract or a mixture of citrus bioflavonoids. J. Nutr., 129(6): 1182-1185.

46. Arabski, M., Węgierek-Ciuk, A., Czerwonka, G., Lankoff, A. and Kaca, W. (2012) Effects of saponins against clinical E. coli strains and eukaryotic cell line. J. Biomed. Biotechnol., 2012. 